\title{
1
}

\section{Responsible Universities in Context}

\author{
Lars Geschwind, Jouni Kekäle, Rómulo Pinheiro, \\ and Mads P. Sørensen
}

\section{Responsible Organisations}

Responsibility has become a catchword in all organisations, and it has become commonplace for business organisations to stress their responsible position and behaviour. The key areas of their attention tend to

\author{
L. Geschwind $(\bowtie)$ \\ KTH Royal Institute of Technology, Stockholm, Sweden \\ e-mail: larsges@kth.se \\ J. Kekäle \\ University of Eastern Finland, Joensuu, Finland \\ e-mail: Jouni.kekale@uef.fi \\ R. Pinheiro \\ Department of Political Science and Management, University of Agder, \\ Kristiansand, Norway \\ e-mail: romulo.m.pinheiro@uia.no \\ M. P. Sørensen \\ Aarhus University, Aarhus, Denmark \\ e-mail:mps@ps.au.dk


include responsibility for the environment, social responsibility, financial responsibility, as well as quality and sustainability issues. The aim is to shape a sustainable future for business and operations and to show that investments in the area serve good purposes not only in terms of profit for stakeholders (as in business organisations) but also in a broader social and ecological sense. ${ }^{1}$

The term 'responsible' has different meanings and connotations depending on the individuals or organisations involved, their immediate geographical, cultural and political contexts, as well as historical periods. According to Webster's (1994) dictionary, the term includes connotations of both (a) being accountable for external powers or stakeholders for one's decision and actions and (b) containing the capacity for one's own (moral) decisions, rational thought and action. In other words, if forced, a person could not be held responsible for the outcomes. There is also a connotation of the responsible actor being reliable or dependable. Synonyms for responsible include accountable, amenable, answerable and liable, whereas antonyms include irresponsible, non-accountable and unaccountable. ${ }^{2}$ Higher education institutions (HEIs) presently make up a large proportion of national gross domestic products (GDPs) and their activities affect many people, including staff, students (and parents), employers and other stakeholders. This impact is particularly so in systems like those in the Nordic countries with high participation rates and significant investments in research. These investments come with expectations. HEIs are expected to contribute to the development and resilience of societies. They are supposed to provide students with high-quality, relevant education, useful in both short term and over time. They are also producers of knowledge, supposedly with an impact on the cultural, social, political, technological and economic development of our societies. Societal demands are thus high, and rightly so, which is shown in an increasingly active debate on higher education (HE) and research.

This volume deals with the notion of responsibility and its relation to HEIs, in particular publicly run and funded universities. Our examples are mainly from the Nordic countries, which are often considered as responsible societies in many ways, for instance, with respect to accountable governments and transparent institutions (Hilson 2008). However, 
our aim is also to provide insights and lessons for the sector as a whole. Given the broad use of the term responsibility, it is no wonder that higher education institutions also feel the need to show that they are operating in a responsible manner. We can identify several reasons for this desire to portray sound operations. First, there appears to be a broad awakening to environmental issues, such as climate change, and other global challenges (Johnsen et al. 2015). Universities are key players in providing new knowledge; hence, it is easy to conclude that they can play a role in overcoming such challenges (Greu et al. 2017). Kaldeway (2018) noted that 'grand challenges' have become a dominant theme in scientific discussions and funding schemes in the twentyfirst century. Universities are perhaps the organisation best positioned to answer issues in need of systematic and long-term thinking and enquiry on any matter. On the other hand, due to their strong social embeddedness (Ramirez 2009), universities tend to take over responsibilities for various kinds of social problems, ${ }^{3}$ perhaps even when they lack the means and measures for promoting such goals. Second, all fashionable concepts and movements tend to spread and produce normative pressure for other fields and operators, thus contributing to the broadening of the use of the concept, both insofar adoption as well as adaptation (Beerkens 2010). Third, we can identify a long-term, external increase of accountability and numerous responsibilities on universities (Hazelkorn et al. 2018), also in the Nordic countries (Hansen et al. 2019; Pinheiro et al. 2019). The expectations on 'responsibility' by universities from multiple stakeholders appear to have persisted (Bok 1982; Neave 2002), but the manifestations and expectations for solutions in reaching 'responsibility' in higher education seem to have changed. In different eras, there have been different assumptions as regards how higher education provides society with public goods (Kekäle et al. 2017); with more recent developments (from Europe) emphasising the instrumental role of universities in directly tackling social issues such as economic development and climate change (Maassen and Olsen 2007). The ongoing discussion on university responsibility, amongst policy and academic circles alike, goes well along with these external pressures. 


\section{The Responsible University: A Concept, Its Relatives and Its Opposites}

The university is not a monolithic single institution, but rather best described as an array of multiple, complex and loosely coupled structures (Pinheiro and Young 2017). The term 'multiversity' (Kerr 2001) has been used as a way of characterising the various, sometimes conflicting, functions and roles that modern university systems address (see also Castells 2001). A number of concepts pertaining to the social role of HEIs can be found in the literature. Like firms, HEIs have started to act in novel, entrepreneurial ways aimed at gradually reducing their dependence on state funding, which amongst other aspects includes adopting marketlike mechanisms (Etzkowitz 2001). Entrepreneurial universities take risks in combining old identities with new structural features such as strengthening their decision-making structures and bridging their core functions with the outside world (Clark 1998). This contrasts with the notion of the 'civic university' where social engagement is intrinsically linked to teaching and research as well as conceived as an institution-wide activity providing academics with a sense of purpose (Goddard et al. 2016). Similarly, Benneworth (2013) and Watson et al. (2011) refer to the 'engaged university' as one where academics and managers take a prominent role in addressing critical issues facing its surrounding communities within the context of social justice and moral responsibility. These range from poverty and social exclusion (inequality) to help in tackling environmental hazards.

More often than not, the aforementioned social challenges best resolve in the form of multiple interdisciplinary collaborations and close collaboration with various stakeholder groups, along the lines of the 'Mode 2' university (Harloe and Perry 2004). The concept of the 'triple helix' has been popular amongst policymakers and university managers alike as a way of conceiving of mutually beneficial interactions between HEIs and public and private actors (Etzkowitz and Leydesdorff 2000). In Europe, the so-called knowledge triangle has emphasised the importance of the social impact derived from HEIs' activities, by strategically articulating the core functions of teaching and research with innovation and engagement as emergent tasks for all HEIs (Maassen and Stensaker 
2011). Finally, North American authors have stressed the important'moral' role played by universities (Berube and Berube 2010), through teaching and youth socialisation, in the context of broader social justice and widespread societal transformations, ranging from gender equality to human rights to racial tolerance to social mobility, and so on. More recently, the rise of fake news in tandem with post-truth, anti-elite and anti-expert knowledge regimes (Nichols 2017; Peters et al. 2018) are challenging traditional conceptions of what counts as legitimate knowledge, putting additional pressures on universities to proactively respond in accordance to their enlightenment and democratically inspired ideals.

Trust towards public institutions and elected officials are good indicators against which to assess the broader social and political climate in which universities, despite their global outlook and orientations, are closely embedded and expected to answer. Recent studies from the US show that in 2018, a mere $48 \%$ of adults expressed confidence in higher education, down from 57\% in 2015 (Inside Higher Education 2018). In the Nordics, annual polls surveying HEIs and their activities still show a high level of confidence towards university employees. Similarly, recent public polls in Norway and Sweden reveal relatively high levels of trust towards research and higher education researchers, but there is some evidence that this faith is also changing (Science Nordic 2018; VA-barometern 2018/2019), and thus it should not be taken for granted. Responsibility is also related to the opposite, that is, to be irresponsible in the meaning of not behaving with honesty, integrity and decency. Throughout the twentieth century, North American research-intensive universities were the subjects of widespread criticism for their proximity to the industrial, military establishment and (indirect) contribution towards the various war efforts (Geiger 2009). Such developments shed further light on the classic cultural rift within academia, between the natural sciences and the social sciences and the humanities (Snow and Collini 2012), with the latter being more critical towards society in general, including external funders such as industry. Earlier inquiries suggest that 'applied' fields are more prone to collaborate with external stakeholders when compared to more basic ones, who tend to be more inner-oriented (Becher and Trowler 2001); yet empirical support for this claim, over the years and across countries, is contested (cf. Pinheiro et al. 2017). 
However, the concept of responsibility also needs some problematisation. In some cases, the opposite-being irresponsible-effectively creates an antidote. There are numerous examples to be found in the media, including several eye-catching cases that have surfaced in the Nordic countries, which challenge the traditional image of trustful Nordic welfare societies with a low level of corruption and deliberate misbehaviour. Probably the most well-known was the Macchiarini affair at Karolinska Institutet in Sweden. Paolo Macchiarini was the Italian former star surgeon who made international headlines when he implanted artificial windpipes into patients but later encountered serious scientific misconduct charges involving fatal consequences (Abbott 2016). Other cases of made up experiments and tests have been revealed as well, with for instance the research at Uppsala University on how fish were affected by plastics, initially published in Nature and internationally recognised before the fraud was proven (Nature 2017).

Conceptions of what is responsible and what is not also change with time and place. In disciplinary fields like philosophy, the distinction may be especially difficult to make. That is why great tolerance has traditionally characterised idealised conceptions of academia. The recent emphasis on short-term accountability and efficiency has set new external expectations, but the dynamics of human invention may not have changed accordingly. Being non-conformist and non-responsive concerning current social expectations might bring long-term benefits and fruitful approaches, but significant innovations and breakthroughs have seldom been accepted overnight (e.g. gravity, electricity). Instead, these innovations encounter considerable scepticism at the onset. There are critical research traditions aimed at social equity, in which uses of power and privileged positions face questioning in attempts to foster more just and equal societies. The concentration of resources may cut down the intellectual and social areas which give meaning and prerequisites for living to many groups of people. Being irresponsible also can signal a sense of genuine autonomy from outside interests and strategic agendas (cooptation) and not being entirely politically correct and adaptive to all of these policies. For example, saying no to third stream/external funding (with perks attached), not adapting as easily as all the others, not being afraid to speak truth to power, and so on. 


\section{Responsibility as a New Thing?}

The role of universities in society, both locally and globally, has been discussed since medieval times. In fact, universities have never been entirely autonomous or isolated from external demands. At the outset, they were deeply rooted in the Christian Church, not only with interlinkages regarding organisation and staff but also based on the kind of education provided. The main aim for a long period of time was to educate the clergy (de Ridder-Symoens 2003). During the late middle ages and the early modern era, universities contributed to the emerging state bureaucracy, educating civil servants to a growing group of clerks, scripters and other administrators. With the establishment of an administrative and judicial state bureaucracy supporting the King there was an increasing demand for educated civil servants. Consequently, law increasingly became a relevant subject area, while universities populated the newly established royal courts in European countries. In the seventeenth and eighteenth centuries also the medical sciences took further steps, albeit modern medicine had to wait until the early nineteenth century to emerge. Even more, the natural sciences prospered, in particular during the eighteenth century when the foundation formed for subsequent breakthroughs. Still, Divinity or Theology remained the noblest, highest ranked discipline, and the curriculum was dominated by works by the classic thinkers, with Latin as the lingua franca of the scholarly world (Huff 2017).

Not until the early nineteenth century did research become one of the main tasks for university professors, landmarked by the foundation of the University of Berlin in 1810 by Wilhelm von Humboldt (Östling 2018). This crucial transition from one university type to another was related to growing and shifting demands from the Prussian state and what became perceived as a university sector in decline. However, the introduction of research and research-based education was only one of the characteristics. Another was the idea of scholarly freedom and autonomy, even detachment from contemporary societal issues. The nineteenth century was an increasingly problematic time for traditional universities to catch up with new demands from industrialisation and emerging capitalism. 
Universities faced criticism for not being up to the task of educating the highly needed professional groups populating offices both in the public and the private sectors. At some universities, external pressure for responsibility led to new faculties, sections and disciplines partially as a response to demands from employers (Wittrock 1993).

At a sector level, the responses from the old, established universities were not considered sufficient. Beginning in the late eighteenth century and continuing throughout the nineteenth century, several new higher education institutions came into existence, including those in the Nordic countries. One specific example included the technical universities focusing on educating engineers for a growing industrialised society. These institutions include KTH Royal Institute of Technology and Chalmers University of Technology in Sweden, Tampere Technical University in Finland, Denmark's Technical University and Norwegian University of Science and Technology, NTNU in Norway. Other both public and private universities opened as well, partly as a response to the existing universities' perceived ability to be responsible. In the aftermath of the Second World War, higher education and research entered a new phase, with a key role in the development of modern welfare societies in the Nordic countries, orchestrated by a designated research and technology policy. During the 1960s, a new expansion wave took place, partly as a result of a much broader democratic movement (Pinheiro and Antonowicz 2015), which opened up universities to a wider public (rising demand) and led to the foundation of a number of new HEIs. Some of these institutions represented a stronger vocational and local character. As a result, most of the Nordic systems entered the mass higher education phase in the 1970s (Trow 2000), supporting the widely shared belief (emanating from human capital theory, cf. Romer 1986) that public investments in education would be beneficial for society as a whole, alongside the idea of higher education as a policy instrument for the development and realisation of the ambitious goals set out by the welfare state (Ahola et al. 2014). Many of the new institutions developed different, distinct profiles than those of the existing universities, as a response to changing demands from society. This period was also the time when binary sectors composed of universities and other types of HEIs were introduced in some countries and considered in most, for various reasons (cf. Kyvik 1981, in the case of Norway). The expansion of the system with a growing student and 
faculty body, and new institutions embracing, for instance, 'interdisciplinarity' changed the geography of higher education and research (Kyvik 1983). The establishment of universities and university colleges across domestic regions also meant that they became increasingly embedded in regional development, for example, as engines of economic growth (Pinheiro et al. 2018).

The last decades, starting with another wave of expansion in the 1990s, have also meant the introduction of new governance ideas in the sector (Neave and van Vught 1991). Still, higher education and research are heavily relying on the public purse for funding and for regulation. However, the former central steering method has been replaced by more formal autonomy and 'steering from a distance' in relation to goals (see e.g. Degn and Sørensen 2015). This changing social contract between higher education (HE) and society, brokered by the state, also meant the opening up of the university to a wide variety of strategic interests and demands from multiple stakeholders (Neave 2002). A related aspect of this changing social contract is the growing neo-liberal idea of a global market for universities where they collaborate and compete. This competition is measured by, and manifested in, for instance, publications, competitive grants and world rankings (Geschwind and Pinheiro 2017).

\section{Global Policy Initiatives}

HE has been recognised as an important sector for addressing global issues such as sustainable development (Gough and Scott 2008). At universities, responsibility can also be linked directly to the sustainability goals of the United Nations (UN). In 2015, the member states of the UN adopted the 2030 Agenda for Sustainable Development and its 17 Sustainable Development Goals (SDGs). ${ }^{4}$ This sustainability agenda deals with areas such as poverty, inequality, climate change, environmental degradation, prosperity, peace and justice. All the (17) goals are rather ambitious. For example, goal number 1 is to 'End poverty in all its forms everywhere'. This goal is specified to 'eradicate extreme poverty for all people everywhere, currently measured as people living on less than $\$ 1.25$ a day' by 2030 and, at the same time, 'reduce at least by half the propor- 
tion of men, women and children of all ages living in poverty' according to national standards for poverty. ${ }^{5}$

These 17 goals could be a framework for universities working with issues of responsibility. Universities have already been called upon to take part in the fulfilment of the SDGs. 'The Sustainable Development Solutions Network (SDSN)_Australia/Pacific' has, for example, published a guide to help universities and other higher education institutions to get started implementing and working with the SDGs. In the guide, it is made clear that universities have a key role to play in the fulfilment of the goals, 'for the SDGs to be truly successful at a global scale, universities need to become champions of sustainable development and play a leading role in the implementation of the SDGs' (SDSN Australia/Pacific 2017). Simultaneously, as functioning organisations, universities face a series of immediate challenges associated with the need to secure external funding, raise quality standards and compete on a global scale, which results in a new set of tensions and dilemmas regarding what functions and whose stakeholders to prioritise (Enders and de Boer 2009; Benneworth and Jongbloed 2010; for a discussion on the Nordics see Pinheiro et al. 2014).

Nordic higher education has been affected by the so-called Europeanisation of the HE space (Maassen and Musselin 2009). The 2000 EU-driven Lisbon Agenda has had a profound effect on the instrumentalisation of the sector in securing policy goals-economic growth and innovation - with HE seen as a critical pillar for enhancing the competitiveness of the region as a whole (Sørensen et al. 2016). As part of this process, and following the suggestions from the EU commission (Aghion et al. 2008), Nordic governments have embarked in a bold agenda aimed at modernising their domestic HE landscapes, including a strengthened focus on university-industry relations and the commercialisation of knowledge (Pinheiro 2015), in addition to mergers or amalgamations (Pinheiro et al. 2016). The establishment of a common European area for HE (Bologna) has enabled the diffusion of standardised practices across national systems, enhancing the convergence of structures, practices and procedures (Witte 2008).

Contemporary societies have several pressing issues to address. A broad yet concrete example is provided by the so-called global challenges (e.g. UN 2019) which are at the forefront of a contemporary 'responsible' 
approach. They are challenging to solve ('wicked problems'), but at least they are stable enough to be studied extensively through academic enquiry. However, seeing, for example, climate change only as an academic problem is insufficient; such problems are also political and practical, embedded deeply in our civilisation and our industrial way of life. In this respect, scientific solutions provide the basis for wider social, political and cultural changes that are required to address such complex problems. This basis for change, in turn, requires action, coordination and collaboration across knowledge domains, sectors and types of organisations, making the emerging concept of 'knowledge co-creation' a rather appealing one amongst policy and managerial circles (Trencher et al. 2013).

Simultaneously, contemporary $\mathrm{HE}$ and research systems, not least in the Nordics, are still based on academic freedom as a core value (cf. Vabø and Aamodt 2008), that is, on the assumption and practices according to which individual scholars assumedly know best what is worth teaching and researching. This approach feeds a culture of trust amongst likeminded academic peers, providing the sustained motivation needed for achieving good results. Calls for increasing instrumentalisation, fiercer competitive pressures and closer ties with external interests, such as those of corporations, governments and funders, create new tensions and dilemmas associated with the need to continue to nurture professional virtues like communism, universalism, independent thinking, organised scepticism and disinterestedness aligned with the traditional ethos of science (Merton 1973).

Responsibility is also an issue closely related to the so-called crisis in science (see, e.g. Saltelli and Funtowicz 2017). This crisis is a double crisis, with both exogenous and endogenous manifestations. On the one hand, it is a trust-crisis. The public seems to lose faith in science due to scandals and questionable scientific results stemming from, among others, scientific scandals and growing political and economic interference in the science system. On the other hand, the crisis is also an endemic crisis within the science system itself. Here, detrimental research practices and replication problems are at the forefront, in addition to unreflected 'gap filling' as a way of motivating research (Alvesson et al. 2017). Studies have shown that many scientific results cannot be reproduced by other scientists (Ioannidis 2005, 2014). This 
leads to a waste of valuable time and funding resources - and can potentially harm universities and the public's trust in science. The causes behind the reproducibility crisis are many. Scientific misconduct in the form of Fabrication, Falsification and Plagiarism (FFP) is potentially very harmful but relatively rare (Fanelli 2009). Therefore, increasing focus has been directed to more widespread detrimental practices; so-called Questionable Research Practices (QRPs) such as p-hacking, selective citing, lack of transparency of methods, and so on (Steneck 2006; Bouter et al. 2016). We still know very little about the root causes of these practices, but publication and funding pressures, as well as the absence of internal quality control, amongst others, seem to be some of the causes. In Europe and elsewhere new projects are emerging designed to better understand and deal with FFP and QRPs. In these projects, emphasis is often put on Research Integrity (see, e.g. EU funded projects such as SOPs4RI: 'Standard Operating Procedures for Research Integrity', VIRT2UE: 'Virtue Based Ethics and Integrity of Research', or EnTIRE: 'The Embassy of Good Science'). 'The European Code of Conduct for Research Integrity' (Allea 2017) is a central policy document in this regard. Further, at the national level, some European countries have made their own codes of conduct to strengthen research integrity (see, e.g. the Danish Code of Conduct: Ministry of Higher Education and Science 2014).

Another interesting example of an emerging discussion on responsibility is the concept of Responsible Research and Innovation (RRI). The latter has become a key term within the European Commission and has, since 2011, been part of the EU's seventh research framework programme and the more recent Horizon 2020 (Owen et al. 2012). RRI builds on the two previous framework programmes' idea of socio-technical integration and has, according to Owen et al. $(2012,757)$, three key dimensions: First, it puts emphasis on 'science for society', that is, it focuses on the 'right impacts' or that science delivers what society needs. Second, there is an emphasis on joining science with society: Science should evolve with the surrounding society. Here, increased institutionalised responsiveness becomes vital. Third, the concept's bridging of responsibility with innovation and research aims at stimulating actors within the field to reflect more critically on their roles and responsibilities as knowledge producers, co-creators and policy advisors. 


\section{Putting Responsibility Into Practice}

We have noted an overall external pressure for increasing accountability or responsibility for universities. Such pressures are buffered and penetrated through academic 'filters', and the outcomes may legitimately, and in practice, vary over time and from place to place. To display this variance of outcomes, we turn to the seminal works of Becher and Kogan (1980) and Clark (1983). Becher and Kogan (1980, 10-20) divide the levels and structure of any higher education system as follows in this section. What is crucial is that each of these levels contributes to outcomes of responsibility in the system, in the manner described:

1. Central level (national and local authorities involved in planning and allocation of resources for HE). National governments, for example, may have their political priorities and tasks, which they may or may not back up with funding for their fulfilment. Such duties, such as life-long learning, inevitably bound resources and tend to rule out alternative possibilities for the use of these scarce resources.

2. Individual institution as defined in the law (with instruments of governance and decision-making bodies). Many countries have undergone changes in university legislation in which institutional autonomy and accountability (responsibility) have been strengthened simultaneously. The institutions ought to profile themselves and create distinct strategies with identified aims, as pertaining to 'procedural autonomy' (Schmidtlein and Berdahl 2005). Institutional funding often connects to the successful fulfilment of these aims. The latter tend to filter the work being done, so that specific issues receive more support and attention than others. What is more, accountability results focusing on ex-post evaluations provide an incentive for gaming, where what gets measured is what gets done (Figlio and Getzler 2006). Prioritising is needed, as Clark $(1998,131)$ notes: 'universities are caught in the cross-fire of expectations', as knowledge increases exponentially and external stakeholders voice their demands. No institution can do it all any longer but must identify core strengths and set strategic priorities. This activity, in turn, affects the ways in which the institution will be able to act responsibly. 
3. Basic Unit (departments, school of study that has academic responsibility). These units need to establish study programmes based on existing research and expertise. Given the deeply rooted and slow to build nature of such programmes, basic units cannot easily change their orientation without slowly developing new expertise through research or recruitments.

4. Individuals (teaching and research staff, administrators and ancillary workers). Academic contributions are strongly dependent on the commitment and motivation of individual scholars (Höhle and Teichler 2013). Since it may take 15-20 years to become an expert in a field, individuals and their research profiles tend to steer how responsibility is taking place. This aspect is highlighted by the considerable academic freedom expressed typically in legislation. For example, in Finland, this fundamental legislative freedom has not changed, although external steering mechanisms and pressures for accountability have increased over time (Kekäle et al. 2017).

Clark $(1983,28)$ noted that academic activities are divided and grouped in two basic ways: by discipline and enterprise. Enterprise refers to different institutional levels. Disciplines guide research questions; they tend to maintain cultures and values, which gather similar-minded scholars together (Becher 1981). Close interaction and cooperation tend to strengthen these values (Kekäle 2001). Since Gibbons et al.'s (1994) seminal work, shedding light on new modes of knowledge production, much has been written on the value and challenges of multidisciplinarity, interdisciplinarity and transdisciplinarity in both teaching and scientific inquiries (Lattuca 2001; Franks et al. 2007). Still, a purely technical university tends to be better equipped for dealing with specific research questions when compared to, for example, an Arts college or a comprehensive university. Undoubtedly, disciplinary traditions and orientations do affect the perspectives, inquiries and values pursued (Becher and Trowler 2001), which again filter the discussion on a given subject. Given the presence of such filters or structural barriers, we contend that rather broad and universalistic aims and outcomes regarding responsibility, as outlined in policy documents and the general media (cf. Aghion et al. 2008), are challenging to realise. Instead, empirically, we are likely to assist the 
emergence of local answers and models to particular (localised) manifestations and interpretations of responsibility in the light of specific contextual circumstances; time, place, people, problems, and so on. The aim is to highlight these in the empirical case studies composing the bulk of this volume.

Clark (1998) noted nearly 20 years ago that there was a widening asymmetry between environmental demands and the institutional capacity to respond; today, this asymmetry has become even more pronounced. Academic excellence, social responsibility, global relevance and more responsiveness to emerging demands with fewer resources are expected. This demand, in turn, has led to mission overload with HEIs struggling to find a new balance between primary tasks (teaching and research) and secondary priorities emanating from the outside from a multiplicity of stakeholder groups (Enders and de Boer 2009). This situation is part of the changing social contract (within the last two decades) between $\mathrm{HE}$ and society, brokered by the state, with the latter being just one of many parties routinely posing new demands on HEIs (Maassen 2014). This phenomenon needs an assessment against the broader set of (new public management) government-led reforms targeting the public sector at large since the 1980s (Christensen and Lægreid 2011). These reforms have, inter alia, emphasised the role of market mechanisms, such as competition and performance management, and resulted in the rise of efficiency and accountability regimes; also in the realm of HE (Hazelkorn et al. 2018), and including the Nordic countries as well (Pinheiro et al. 2019).

Contemporary debates surrounding HEIs' third mission (of social engagement) have emphasised the role played by HEIs in the transfer of knowledge to society and firms, as engines for economic development and global competitiveness (Harding et al. 2007), and/or bastions for revitalising the socio-cultural profile of cities, regions and states (Laredo 2007). Studies have investigated the interplay between the third mission and the traditional core functions of teaching and research, with overwhelming evidence suggesting higher levels of structural decoupling (Benneworth 2012; Pinheiro et al. 2018). The third mission has gained new momentum in the last decade, as HEIs look for ways to distinguish themselves in a highly competitive market place, including the quest for 
new revenue streams and patrons (Pinheiro et al. 2015). Significant tensions remain, not least when it comes to finding an adequate balance between local engagement/relevance and global excellence, even though the two are not mutually exclusive (cf. Pinheiro 2016).

\section{Higher Education in the Nordic Countries: Some Key Features}

Nordic higher education has been the target of major governmental reforms in the last two decades. On the whole, these reforms have focused on strengthening the autonomy of institutions whilst at the same time enacting structural changes in the internal fabric of HEIs to foster efficiency, accountability and excellence. Managerialist-related features have been at the top of the agenda, with a strengthened focus given to changes in the governance structures of HEIs as well as the introduction of performance-based mechanisms within teaching and research (Vabø and Aamodt 2008). Teaching quality and research (world class) excellence have also featured centrally, as part of a gradual but steady move towards an enterprise-like market-based model centred on rankings and global competition (Geschwind and Pinheiro 2017).

When result-oriented management appeared in the late 1980s and early 1990s in the Nordic countries, university budgets began to include performance-based funding. Furthermore, funders have requirements for research outcomes, which effectively steers projects towards these goals, what some have termed the rise of 'strategic science regimes' (Rip 2004). Since the national legal frameworks regulating Nordic HE have been renewed to foster efficiency and accountability, quality assurance mechanisms have been introduced, structural development and mergers have been carried out, leadership practices have become less collegial and more leader-centred (Degn and Sørensen 2015; Pinheiro et al. 2019). There have been cascading reforms aiming at increasing relevance, accountability and efficiency within the given timeframe, leading (perhaps) to mission overload. Financial steering and competition may increase research efficiency but the benefits appear to be only temporary 
due to complex regulations by multiple funders, short-term agreements, the accumulation of research funding by academic elite groups, the socalled Matthew effects (Kwiek 2018), and potential clashes with educational values and cultures (Auranen 2014).

Governments across the Nordic region have enacted a variety of reforms aimed at making HEIs more accountable for their own actions and more responsive to external demands and expectations. From an initial look at Norway, the 2003/2004 Quality Reform led to the establishment of a series of governance and leadership changes within HEIs, for example, performance-based management and external actors playing a key role at the board level. Likewise, the Bologna process and the creation of a national agency for quality assurance led to increased oversight, most notably for non-university institutions such as university colleges. A system of contracts came to the fore, changing the relationship between HEIs and the Ministry from one based on trust towards a more transactional arrangement based on agreed-upon strategic goals and tangible outcomes. Societal engagement ('formidling') officially became a task for all HEIs, including the research-intensive ('flagship') universities such as Oslo, Bergen and the Norwegian University of Science and Technology (NTNU). In 2015, and for the first time, the Norwegian government adopted a long-term (2015-2024) plan for research and HE, outlining the need to concentrate resources in areas of national strategic importance (seas, climate, health care, etc.) and as a means of securing world class research excellence on a global scale (Kunnskapsdepartementet 2015). Amongst other aspects, the report stresses the responsibility of the public sector, HEIs included, in helping tackling both local and global problems, which entails 'a responsibility for bringing their best experts forward' (Ibid., p. 44).

In Finland, the most profound of the recent changes in HE policy is the new Universities Act (558/2009) of 2009. Although the act was a fundamental move, it can be seen to be well in line with the overall longterm development in HE and the university-society relationship: increasing institutional autonomy, albeit within the framework of greater accountability (responsibility). Aarrevaara et al. (2009) reported that the essence of the reform is that the overall responsibility for improving the conditions of the division of labour will be transferred to the universities as they will become independent legal entities. According to the Ministry 
of Education, the aim was to increase top international expertise, establish stronger and more effective higher education units, and improve the competitiveness of the university system with better professional management.

It is, according to the university law, the responsibility of universities in Denmark to 'conduct research and offer research-based education at the highest international level within its academic fields' (University Act 2011). Further, the University Act states that universities also have an obligation to collaborate with the surrounding society, to contribute to the development of international collaboration, to contribute to promoting growth, prosperity and the development of society. The university is also by law obligated to exchange knowledge and competences with society and encourage its employees to take part in the public debate (University Act 2011).

Also, in the Swedish higher education legislation, there are references to responsibility. The steps taken towards increased formal autonomy for higher education institutions by reforms in 1993 and 2011 have accentuated the need for responsible action. It reflects in the Higher Education Act that HEIs should collaborate with the surrounding society and inform these societies of their activities as well as work for research results to come to use. Furthermore, actions should be undertaken with the highest possible efficiency, effectiveness and quality as well as trustworthiness and ethics. HEIs are also expected to contribute to a sustainable development and gender equality, provide international perspectives, and promote widening participation (Högskolelag 1992/1434).

In short, Nordic HEIs are faced with increasing pressures to be both responsive and responsible, and this volume is a first attempt to take stock of ongoing developments across the Nordic countries, including shedding light on key trends and tensions, trade-offs and dilemmas as well as illuminating possible ways ahead in the Nordic countries and beyond. Some of the contributions in this volume problematise the geographical dimension of higher education in its relation to responsibility: how can a university contribute to society in various contexts? Both the regional and global dimensions surface for discussion in empirical chapters. Other contributions are more focused on how the core activities, research and education, are undertaken, for instance, in the form of so- 
called co-creation of knowledge, interdisciplinarity or massive open online courses (MOOC) and publication strategies related to languages, in particular the role of English as the scientific lingua franca. Last but not least, the internal, organisational procedures and practices are under discussion, as in recruitment processes and various 'irresponsible repertoires', that is, how university management can find themselves in responsibility dilemmas, potentially breaching the public value. Altogether the volume provides an array of examples of, and critical discussions of, the 'responsible university', it challenges, opportunities, in particular in the Nordic countries, but also beyond.

\section{Notes}

1. See, for example, http://www.responsiblebusiness.com/.

2. https://www.merriam-webster.com/dictionary/responsible\#other-words.

3. https://www.eairweb.org/forum.

4. https://www.un.org/sustainabledevelopment/.

5. https://www.un.org/sustainabledevelopment/poverty/.

\section{References}

Aarrevaara, T., Dobson, I., \& Elander, C. (2009). Brave New World: Higher Education Reform in Finland. Higher Education Management and Policy, 21(2), 89-106.

Abbott, A. (2016). Medical Nobel Prize Committee Deals with Surgical Scandal. Nature News, 537(7620), 289.

Aghion, P., Dewatripont, M., Hoxby, C., Mas-Colelle, M., \& Sapir, A. (2008). Higher Aspirations: An Agenda for Reforming European Universities. Brussels: Bruegel.

Ahola, S., Hedmo, T., Thomsen, J. P., \& Vabø, A. (2014). Organisational Features of Higher Education. Denmark, Finland, Norway and Sweden. NIFU Working Paper 2014:14. Oslo: NIFU.

Allea. (2017). The European Code of Conduct for Research Integrity. Retrieved from https://ec.europa.eu/research/participants/data/ref/h2020/other/hi/ h2020-ethics_code-of-conduct_en.pdf. 
Alvesson, M., Gabriel, Y., \& Paulsen, R. (2017). Return to Meaning: A Social Science with Something to Say. New York: OUP Oxford.

Auranen, O. (2014). University research performance: Influence of funding competition, policy steering and micro-level factors. $\mathrm{PhD}$ Thesis, University of Tampere. Tampere: Tampere University Press.

Becher, T. (1981). Towards a Definition of Disciplinary Cultures. Studies in Higher Education, 6(2), 109-122.

Becher, T., \& Kogan, M. (1980). Process and Structure in Higher Education. London: Heinemann.

Becher, T., \& Trowler, P. (2001). Academic Tribes and Territories: Intellectual Enquiry and the Culture of Disciplines. Buckingham: Society for Research into Higher Education \& Open University Press.

Beerkens, E. (2010). Global Models for the National Research University: Adoption and Adaptation in Indonesia and Malaysia. Globalisation, Societies and Education, 8(3), 369-381.

Benneworth, P. (2012). The Relationship of Regional Engagement to Universities' Core Purposes: Reflections from Engagement Efforts with Socially Excluded Communities. In R. Pinheiro, P. Benneworth, \& G. A. Jones (Eds.), Universities and Regional Development: A Critical Assessment of Tensions and Contradictions. Milton Park and New York: Routledge.

Benneworth, P. (2013). University Engagement with Socially Excluded Communities. Dordrecht: Springer.

Benneworth, P., \& Jongbloed, B. (2010). Who Matters to Universities? A Stakeholder Perspective on Humanities, Arts and Social Sciences Valorisation. Higher Education, 59(5), 567-588. https://doi.org/10.1007/s10734-009-9265-2.

Berube, M. R., \& Berube, C. T. (2010). The Moral University. New York and Toronto: Rowman \& Littlefield Publishers.

Bok, D. C. (1982). Beyond the Ivory Tower: Social Responsibilities of the Modern University. Cambridge, MA: Harvard University Press.

Bouter, L. M., Tijdink, J., Axelsen, N., Martinson, B. C., \& Riet, G. t. (2016). Ranking Major and Minor Research Misbehaviors: Results from a Survey Among Participants of Four World Conferences on Research Integrity. Research Integrity and Peer Review, 1, 17.

Castells, M. (2001). Universities as Dynamic Systems of Contradictory Functions. In J. Muller, N. Cloete, \& S. Badat (Eds.), Challenges of Globalisation. South African Debates with Manuel Castells (pp. 206-233). Cape Town: Maskew Miller Longman.

Christensen, T., \& Lægreid, P. (2011). The Ashgate Research Companion to New Public Management. Surrey: Ashgate. 
Clark, B. R. (1983). The Higher Education System. Academic Institutions on CrossNational Perspective. Berkeley: University of California Press.

Clark, B. R. (1998). Creating Entrepreneurial Universities: Organizational Pathways of Transformation. New York: Pergamon.

De Ridder-Symoens, H. (2003). A History of the University in Europe: Volume 1, Universities in the Middle Ages (Vol. 1). Cambridge: Cambridge University Press.

Degn, L., \& Sørensen, M. P. (2015). From Collegial Governance to Conduct of Conduct: Danish Universities Set Free in the Service of the State. Higher Education, 69(6), 931-946.

Enders, J., \& de Boer, H. (2009). The Mission Impossible of the European University: Institutional Confusion and Institutional Diversity. In A. Amaral, G. Neave, C. Musselin, \& P. Maassen (Eds.), European Integration and the Governance of Higher Education and Research (Vol. 26, pp. 159-178). Dordrecht: Springer.

Etzkowitz, H. (2001). The Second Academic Revolution and the Rise of Entrepreneurial Science. Technology and Society Magazine, 20(2), 18-29.

Etzkowitz, H., \& Leydesdorff, L. (2000). The Dynamics of Innovation: From National Systems and "Mode 2" to a Triple Helix of University-IndustryGovernment Relations. Research Policy, 29(2), 109-123.

Fanelli, D. (2009). How Many Scientists Fabricate and Falsify Research? A Systematic Review and Meta-Analysis of Survey Data. PLoS ONE, 4(5), e5738.

Figlio, D. N., \& Getzler, L. S. (2006). Accountability, Ability and Disability: Gaming the System? In T. Gronberg \& D. Jansen (Eds.), Improving School Accountability (pp. 35-49). Bingley: Emerald Group Publishing Limited.

Franks, D., Dalea, P., Hindmarsha, R., Fellows, C., Buckridgea, M., \& Cybinskia, P. (2007). Interdisciplinary Foundations: Reflecting on Interdisciplinarity and Three Decades of Teaching and Research at Griffith University, Australia. Studies in Higher Education, 32(2), 167-185.

Geiger, R. L. (2009). Research \& Relevant Knowledge: American Research Universities Since World War II. New Jersey: Transaction Publishers.

Geschwind, L., \& Pinheiro, R. M. (2017). Raising the Summit or Flattening the Agora? The Elitist Turn in Science Policy in Northern Europe. Journal of Baltic Studies, 48(4), 513-528. https://doi.org/10.1080/01629778.2 017.1305178.

Gibbons, M., Limoges, C., Noworthy, H., Schwartzman, S., Scott, P., \& Trow, M. (1994). The New Production of Knowledge. The Dynamics of Science and Research in Contemporary Societies. London: Sage. 
Goddard, J., Hazelkorn, E., \& Vallance, P. (2016). The Civic University: The Policy and Leadership Challenges. Cheltenham: Edward Elgar Publishing. Gough, S., \& Scott, W. (2008). Higher Education and Sustainable Development: Paradox and Possibility. New York: Taylor \& Francis.

Grau, F.X., Goddard, J., Hazelkorn, E., \& Tandon, R. (2017). Recommendations for Academia, Academic Leaders and Higher Education and Research Policymakers. In Grau, et al. (Eds.), Towards a Socially Responsible Higher Education Institution: Balancing the Global with the Local. GUNI - Global University Network for Innovation. Higher Education in the World. Towards a Socially Responsible University: Balancing the Global with the Local. Retrieved from http://www.guninetwork.org/report/higher-educationworld-6.

Hansen, H. F., Geschwind, L., Kivistö, J., Pekkola, E., Pinheiro, R., \& Pulkkinen, K. (2019). Balancing Accountability and Trust: University Reforms in the Nordic Countries. Higher Education (online first). https:// doi.org/10.1007/s10734-019-0358-2.

Harding, A., Scott, A., Laske, A., \& Burtscher, C. (Eds.). (2007). Bright Satanic Mills: Universities, Regional Development and the Knowledge Economy. Aldershot: Ashgate.

Harloe, M., \& Perry, B. (2004). Universities, Localities and Regional Development: The Emergence of the 'Mode 2'University? International Journal of Urban and Regional Research, 28(1), 212-223.

Hazelkorn, E., Coates, H., \& McCormick, A. C. (2018). Research Handbook on Quality, Performance and Accountability in Higher Education. Cheltenham and Northampton: Edward Elgar Publishing.

Hilson, M. (2008). The Nordic Model: Scandinavia Since 1945. London: Reaktion Books.

Högskolelag. (1992/1434). Retrieved from https://www.riksdagen.se/sv/dokument-lagar/dokument/svensk-forfattningssamling/hogskolelag-19921434_ sfs-1992-1434.

Höhle \& Teichler. (2013). Determinants of Academic Job Satisfaction in Germany. In P. Bentley, H. Coates, I. R. Dobson, L. Goedegebuere, \& V. L. Meek (Eds.), Job Satisfaction Around the Academic World (pp. 125-133). Dordrecht: Springer. https://doi.org/10.1007/978-94-007-5434-8_7.

Huff, T. E. (2017). The Rise of Early Modern Science: Islam, China, and the West. Cambridge: Cambridge University Press.

Inside Higher Education. (2018). Retrieved from https://www.insidehighered. com/news/2018/10/09/gallup-survey-finds-falling-confidence-highereducation. 
Ioannidis, J. P. (2005). Why Most Published Research Findings Are False. PLoS Med, 2(8), e124.

Ioannidis, J. P. (2014). How to Make More Published Research True. PLoS Med, 11(10), e1001747.

Johnsen, H., Torjesen, S., \& Ennals, R. (2015). Higher Education in a Sustainable Society. London: Springer International Publishing.

Kaldeway, D. (2018). The Grand Challenges Discourse: Transforming Identity Work in Science and Science Policy. Minerva, 56(2), pp. 161-182. Retrieved from https://link.springer.com/article/10.1007/s11024-017-9332-2.

Kekäle, J. (2001). Academic Leadership. New York: Nova Science Publishers.

Kekäle, J, Diogo, S., \& Varis, J. (2017). Changes in the University-Society Relationship and Its Outcomes in Major Higher Education Reforms in Finland. A Paper Presented at the Good University Aarhus Workshop. Unpublished Manuscript.

Kerr, C. (2001). The Uses of the University. Cambridge, MA: Harvard University Press.

Kunnskapsdepartementet. (2015). Long-term Plan for Research and Higher Education. Retrieved from Oslo. Retrieved from https://www.regjeringen. no/contentassets/e10e5d5e2198426788ae4f1ecbbbbc20/en-gb/pdfs/ stm201420150007000engpdfs.pdf.

Kwiek, M. (2018). High Research Productivity in Vertically Undifferentiated Higher Education Systems: Who Are the Top Performers? Scientometrics, 115(1), 415-462.

Kyvik, S. (1981). The Norwegian Regional Colleges: A Study of the Establishment and Implementation of a Reform in Higher Education. Oslo: Norwegian Institute for Studies in Research and Higher Education.

Kyvik, S. (1983). Decentralisation of Higher Education and Research in Norway. Comparative Education, 19(1), 21-29.

Laredo, P. (2007). Revisiting the Third Mission of Universities: Toward a Renewed Categorization of University Activities? Higher Education Policy, 20(4), 441-456.

Lattuca, L. R. (2001). Creating Interdisciplinarity: Interdisciplinary Research and Teaching Among College and University Faculty. Nashville: Vanderbilt University Press.

Maassen, P. (2014). A New Social Contract for Higher Education? In G. Goastellec \& F. Picard (Eds.), Higher Education in Societies (pp. 33-50). Rotterdam: SensePublishers.

Maassen, P., \& Musselin, C. (2009). European Integration and the Europeanisation of Higher Education. In European Integration and the Governance of Higher Education and Research (pp. 3-14). Dordrecht: Springer. 
Maassen, P., \& Olsen, J. P. (2007). University Dynamics and European Integration. Dordrecht: Springer.

Maassen, P., \& Stensaker, B. (2011). The Knowledge Triangle, European Higher Education Policy Logics and Policy Implications. Higher Education, 61(6), 757-769.

Merton, R. K. (1973). The Sociology of Science: Theoretical and Empirical Investigations. Chicago: University of Chicago Press.

Ministry of Higher Education and Science. (2014). Danish Code of Conduct for Research Integrity. Copenhagen. Retrieved from https://ufm.dk/en/publications/2014/the-danish-code-of-conduct-for-research-integrity.

Nature. (2017). Investigation Finds Swedish Scientists Committed Scientific Misconduct. Probe centered on controversial paper that claimed microplastic pollution harms fish. Retrieved from https://www.nature.com/articles/ d41586-017-08321-2.

Neave, G. (2002). The Stakeholder Perspective Historically Explored. In J. Enders \& O. Fulton (Eds.), Higher Education in a Globalising World: International Trends and Mutual Observations: A Festschrift in Honour of Ulrich Teichler (pp. 17-37). Berlin: Springer.

Neave, G., \& van Vught, F. (1991). Prometheus Bound: The Changing Relationship Between Government and Higher Education in Western Europe. Oxford: Pergamon.

Nichols, T. (2017). The Death of Expertise: The Campaign Against Established Knowledge and Why It Matters. New York: Oxford University Press.

Östling, J. (2018). Humboldt and the Modern German University: An Intellectual History. Lund: Lund University Press.

Owen, R., Macnaghten, P., \& Stilgoe, J. (2012). Responsible Research and Innovation: From Science in Society to Science for Society, with Society. Science and Public Policy, 39(2012), 751-760.

Peters, M. A., Rider, S., Hyvönen, M., \& Besley, T. (2018). Post-Truth, Fake News: Viral Modernity \& Higher Education. Singapore: Springer.

Pinheiro, R. (2015). Citius, Altius, Fortius: Mobilising the University for the 'Europe of Knowledge'. In B. Culum, F. Robeiro, \& Y. Politis (Eds.), New Voices in Higher Education Research and Scholarship (pp. 1-17). Hershey, PA: IGI-Global.

Pinheiro, R. (2016). Assessing Change in Higher Education from the Perspective of Excellence Versus Relevance. In N. Cloete, L. Goedegebuure, Å. Gornitzka, J. Jungblut, \& B. Stensaker (Eds.), Pathways Through Higher Education Research: A Festschrift in Honour of Peter Maassen (pp. 37-40). Oslo: University of Oslo. 
Pinheiro, R., \& Antonowicz, D. (2015). Opening the Gates or Coping with the Flow? Governing Access to Higher Education in Northern and Central Europe. Higher Education, 70(3), 299-313.

Pinheiro, R., Geschwind, L., \& Aarrevaara, T. (2014). Nested Tensions and Interwoven Dilemmas in Higher Education: The View from the Nordic Countries. Cambridge Journal of Regions, Economy and Society, 7(2), 233-250. https://doi.org/10.1093/cjres/rsu002.

Pinheiro, R., Geschwind, L., \& Aarrevaara, T. (Eds.). (2016). Mergers in Higher Education: The Experiences from Northern Europe, Higher Education Dynamics. Dordrecht: Springer.

Pinheiro, R., Geschwind, L., Hansen, H., \& Pulkkinen, K. (Eds.). (2019). Reforms, Organizational Change and Performance in Higher Education: A Comparative Account from the Nordic Countries. Cham: Palgrave.

Pinheiro, R., Langa, P., \& Pausits, A. (2015). One and Two Equals Three? The Third Mission of Higher Education Institutions. European Journal of Higher Education, 5(3), 233-249.

Pinheiro, R., Normann, R., \& Johnsen, H. C. G. (2017). External Engagement and the Academic Heartland: The Case of a Regionally-embedded University. Science and Public Policy, 43(6), 787-797.

Pinheiro, R., \& Young, M. (2017). The University as an Adaptive Resilient Organization: A Complex Systems Perspective. In J. Huisman \& M. Tight (Eds.), Theory and Method in Higher Education Research (pp. 119-136). Bingley: Emerald.

Pinheiro, R., Young, M., \& Sima, K. (2018). Higher Education and Regional Development: Tales from Northern and Central Europe. Cham: Palgrave.

Ramirez, F. O. (2009). World Society and the Socially Embedded University. 사 회과학논집, $40(2), 1-30$.

Rip, A. (2004). Strategic Research, Post-modern Universities and Research Training. Higher Education Policy, 17(2), 153-166.

Romer, P. (1986). Increasing Returns and Long-Run Growth. Journal of political economy, 94(5), 1002-1037.

Saltelli, A., \& Funtowicz, S. (2017). What is science's crisis really about? Futures, 91, 5-11.

Schmidtlein, F., \& Berdahl, R. (2005). Autonomy and Accountability: Who Controls Academe? In P. Altbach, R. Berdahl, \& P. Gumport (Eds.), American Higher Education in the Twenty-First Century: Social, Political, and Economic Challenges (pp. 71-90). Baltimore: John Hopkins University Pres.

Science Nordic. (2018). Retrieved from http://sciencenordic.com/swedishwomen-less-trusting-researchers. 
SDSN Australia/Pacific. (2017). Getting Started with the SDGs in Universities: A Guide for Universities, Higher Education Institutions, and the Academic Sector. Australia, New Zealand and Pacific Edition. Sustainable Development Solutions Network - Australia/Pacific, Melbourne. Retrieved from http:// ap-unsdsn.org/wp-content/uploads/University-SDG-Guide_web.pdf.

Snow, C. P., \& Collini, S. (2012). The Two Cultures. London: Cambridge University Press.

Sørensen, M. P., Young, M., \& Bloch, C. (2016). Excellence in the KnowledgeBased Economy: From Scientific to Research Excellence. European Journal of Higher Education, 6(3), 217-236. https://doi.org/10.1080/21568235.2 015.1015106.

Steneck, N. H. (2006). Fostering Integrity in Research: Definitions, Current Knowledge, and Future Directions. Science and Engineering Ethics, 12, 53-74. Trencher, G., Yarime, M., McCormick, K. B., Doll, C. N., \& Kraines, S. B. (2013). Beyond the Third Mission: Exploring the Emerging University Function of Cocreation for Sustainability. Science and Public Policy, 41(2), 151-179.

Trow, M. (2000). From Mass Higher Education to Universal Access: The American Advantage. Minerva, 37(4), 303-328.

UN. (2019). https://sustainabledevelopment.un.org/?menu=1300.

University Act. (2011). Retrieved from https://ufm.dk/en/legislation/prevailing-laws-and-regulations/education/files/the-danish-university-act.pdf.

VA-barometern. (2018/2019). VA-rapport 2018:6. Stockholm: Vetenskap och Allmänhet. Retrieved from https://v-a.se/downloads/varapport2018_6.pdf. Vabø, A., \& Aamodt, P. O. (2008). Nordic Higher Education in Transition. In T. Tapper \& D. Palfreyman (Eds.), Structuring Mass Higher Education. The Role of Elite Institutions. London: Routdlege.

Watson, D., Hollister, R., Stroud, S. E., \& Babcock, E. (2011). The Engaged University: International Perspectives on Civic Engagement (1st ed.). London: Routledge.

Webster's. (1994). Encyclopedic Unabridged Dictionary of the English Language. New York: Gramercy Books.

Witte, J. (2008). Aspired Convergence, Cherished Diversity: Dealing with the Contradictions of Bologna. Tertiary Education and Management, 14(2), 81-93. https://doi.org/10.1080/135838808020518.

Wittrock, B. (1993). The Modern University: The Three Transformations. In S. Rothblatt \& B. Wittrock (Eds.), The European and American University Since 1800. Historical and Sociological Essays. Cambridge: Cambridge University Press. 
Open Access This chapter is licensed under the terms of the Creative Commons Attribution 4.0 International License (http://creativecommons.org/licenses/ by/4.0/), which permits use, sharing, adaptation, distribution and reproduction in any medium or format, as long as you give appropriate credit to the original author(s) and the source, provide a link to the Creative Commons licence and indicate if changes were made.

The images or other third party material in this chapter are included in the chapter's Creative Commons licence, unless indicated otherwise in a credit line to the material. If material is not included in the chapter's Creative Commons licence and your intended use is not permitted by statutory regulation or exceeds the permitted use, you will need to obtain permission directly from the copyright holder.

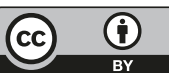

